\title{
Applications of NMR spectroscopy in understanding the gold biochemistry
}

\author{
Anvarhusein A. Isab ${ }^{\mathrm{a}, *}$ and Saeed Ahmad ${ }^{\mathrm{b}}$ \\ ${ }^{a}$ Department of Chemistry, King Fahd University of Petroleum and Minerals, Dhahran 31261, \\ Saudi Arabia \\ ${ }^{\mathrm{b}}$ Department of Chemistry, University of Engineering and Technology, Lahore, Pakistan
}

This article is dedicated to Professor P.J. Sadler FRS on his 60th Birthday

\begin{abstract}
Gold-based drugs have been successfully used for the treatment of rheumatoid arthritis. When administered, they undergo ligand exchange reactions in the body with biofluids, cells and proteins. NMR spectroscopy is a very useful technique for probing these ligand exchange reactions under physiological conditions. The strength of the binding ligands can be estimated by studying the chemical shift changes in ${ }^{13} \mathrm{C}$ and ${ }^{31} \mathrm{P}$ NMR. It is also a powerful method for investigating the kinetics and thermodynamics of the exchange reactions of gold drugs with biomolecules. The purpose of this review report is to highlight the importance of NMR spectroscopy in the study of gold biochemistry and to bridge the fairly large gap in the progress of this interesting area of bioinorganic chemistry.
\end{abstract}

\section{Introduction}

The first use of gold compounds for the treatment of rheumatoid arthritis (pain in joints) was reported by Lande in 1929 and since then they have been in clinical use as anti-arthritic agents. The most widely used gold drugs are; gold(I) thiomalate [myocrisin (Autm)], gold(I) thioglucose [solganol (Autg)] and auranofin [2,3,4,6-tetra-o-acetyl-1-thio- $\beta$-D-glucopyranosato-S) triethylphosphine gold(I)] [1-3]. Besides treating arthritis, a large number of phosphine gold(I) complexes, for example, auranofin and $\left[\mathrm{Au}(\mathrm{dppe})_{2}\right] \mathrm{Cl}$ (dppe = 1,2-bis(diphenylphosphino)ethane) are also known to exhibit promising antitumor properties [4-9]. Structures of some gold drugs with their trade names are shown in Fig. 1.

Myocrisin and solganol are water soluble but insoluble in hydrophobic environments and thus have to be administered intramuscularly to prevent hydrolysis in acid gastric fluid. The lipophilic auranofin on the other hand can be administered orally [1,2]. Auranofin possesses several potential advantages over the other gold drugs. These are oral administration, less kidney retention, equal distribution between the cellular components and serum proteins of the blood and inhibition of release of lysosomal enzymes, which are responsible for tissue damages [10]. The crystal structure of auranofin shows that gold is linearly coordinated by the sulfur atom of thioglucose and the phosphorus of $\mathrm{Et}_{3} \mathrm{P}$ to give a discrete monomeric molecular species [11]. Gold thiolates are polymeric in nature [12-14] (by sulfur bridging)

\footnotetext{
${ }^{*}$ Corresponding author. E-mail: aisab@kfupm.edu.sa.
} 
<smiles>NC(=O)CC(S[AlH2])C(=O)O</smiles>

Myocrisin

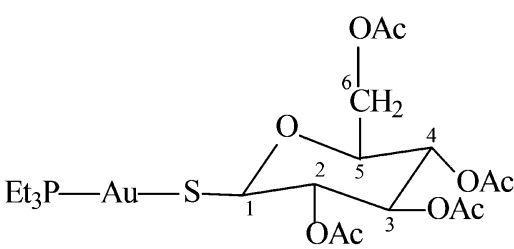

Auranofin<smiles>OCC1OC(S[AlH2])C(O)C(O)C1O</smiles>

Solganol

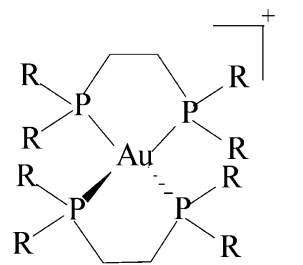

Bis(diphos)gold(I) Chloride $(\mathrm{R}=\mathrm{Ph})$

Fig. 1. Structures of some important gold drugs.

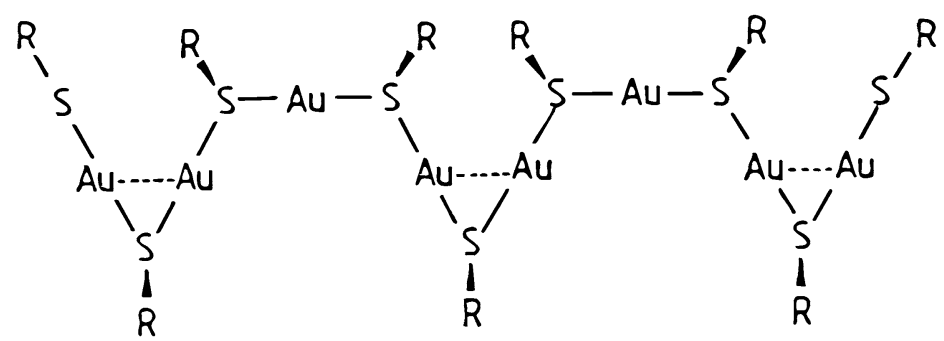

$\mathrm{R}=$ Thiomalate or Thioglucose

Fig. 2. Polymeric structure of gold(I) thiolates.

with a gold-gold interaction (Fig. 2). The structures of these polymers are very sensitive to the ionic strength and $\mathrm{pH}$ of the solutions [15].

The antiarthritic activity of gold(I) compounds may be related to the high affinity and selectivity of gold(I) for sulfhydryl sulfur as a biological ligand [16]. Since gold(I) is extremely labile, these gold(I) complexes after their administration, undergo several ligand exchange reactions in the body with biofluids, cells and proteins [10,17-20]. The high affinity of gold(I) for sulfur and selenium ligands suggests that proteins including enzymes and transport proteins will be critical in vivo targets. Serum albumin, the principal extra cellular protein of blood, binds to about $90 \%$ of the gold in serum and functions as a defecto transport agent [21]. With their chain structures, gold thiolates have a capacity, to react rapidly with a variety of ligands, like thiols, thiones, selenols and cyanide, while the reactions of auranofin are slower because of the strong binding of both ligands (triethylphosphine and thioglucose) to gold(I) $[10,17,22-25]$. Gold(I) thiolates, (Gold(I), thiomalate and thioglcose) being polymers can not enter red blood cells (RBCs) [26,27], while auranofin being monomeric does enter into RBCs immediately after 
its absorption and binds to intracellular glutathione (GSH) and Cys- $\beta-93$ 's of hemoglobin $(\mathrm{Hb})$ [25]. The RBCs, which contain thiol and thione ligands, e.g., GSH, Hb and ergothionine (ErS), can form stable complexes with gold drugs [25,28]. Gold has no known biological function in the body and hence there are no natural mechanisms for gold in the body. Therefore toxic effects may arise by the use of gold drugs [10]. Toxic effects generally appear on skin, mucous membrane including gastrointestinal and renal problems.

NMR spectroscopy being a non-invasive method has found successful applications in the characterization of several species formed as a result of the drug action and thus allows studying several physiological consequences of the drugs [29]. The exchange reactions of gold(I) drugs with various biological ligands have been studied in detail using NMR spectroscopy [17,25-30]. Proton, carbon-13 and nitrogen-15 NMR have proved to be very useful in the structural characterization of gold thiolates metabolites [17, 30-32]. The sensitivity of ${ }^{13} \mathrm{C}$ and ${ }^{15} \mathrm{~N}$ can be enhanced by using isotopically enriched samples or by polarization transfer techniques such as INEPT or DEPT. The phosphorus-31 nucleus with $100 \%$ natural abundance and high sensitivity makes ${ }^{31} \mathrm{P}$ NMR the most widely used technique for investigating the reactions of auranofin [29]. The ${ }^{31} \mathrm{P}$ chemical shift is sensitive to the nature of the trans coordinated ligand and release of $\mathrm{Et}_{3} \mathrm{P}$ can be monitored by observation of $\mathrm{Et}_{3} \mathrm{PO}$ resonance $[18,19,24,25,33]$. Changes in intensity of the resonances with time are helpful to follow the kinetics of the exchange reactions [34]. This article describes a detailed review of the use of NMR spectroscopy in following the exchange reactions of anti-rheumatic gold(I) complexes with various biologically important ligands. The applications of NMR to study the structure-activity relationship are highlighted that would help in designing novel gold drugs and understanding their mechanism of action.

\section{Interaction of gold drugs with thiols}

Proton and carbon-13 NMR are successfully applied to monitor the exchange reactions of (Autm) ${ }_{n}$ with thiols. The ${ }^{1} \mathrm{H}$ and ${ }^{13} \mathrm{C}$ NMR studies of the interaction of (Autm) ${ }_{n}$ with thiomalate suggest the formation of new species with thiolate: Au ratio of 1.75:1.0 according to Eq. (1), which undergoes slow exchange with Htm [17].

$$
4(\mathrm{Autm})_{n}+3 \mathrm{Htm} \Leftrightarrow\left[\mathrm{Au}_{4}(\mathrm{tm})_{7}\right]^{3-}+3 \mathrm{H}^{+} .
$$

The breakdown of (Autm) $)_{n}$ polymer occurs by a similar route for other thiols such as cysteine [17]. The kinetic analysis of these reactions showed that they proceed through associative mechanism [17]. Generally it is established that reaction of thiols to $[\mathrm{Au}(\mathrm{SR})]_{n}$ polymers results in the formation of bis(thiolate)aurate(I) species, which undergoes rapid exchange with additional ligand $[35,36]$. Thiols with lower $\mathrm{pK}_{\mathrm{a}}$ values are in fast exchange with gold(I) and the resonances for free and bound thiomalate could be observed only for thiols with $\mathrm{pK}_{\mathrm{a}}$ greater than $9 .{ }^{13} \mathrm{C}$ NMR studies suggest that thiols with the lowest $\mathrm{pK}_{\mathrm{a}}$ values bind most strongly to gold(I). Thus binding of gold drugs with cysteine $\left(\mathrm{pK}_{\mathrm{a}}=8.5\right)$ will be thermodynamically more favored over glutathione $\left(\mathrm{pK}_{\mathrm{a}}=8.9\right)$. Due to ease of thiol exchange reactions, gold distribution in the body after drug treatment is very wide spread [17].

The interaction of (Autm) $)_{n}$ with glutathione and the red blood cells has been studied by spin echo ${ }^{1} \mathrm{H}$ NMR $[27,30]$. As (Autm) ${ }_{n}$ is titrated with glutathione, a specific binding of gold to cysteine of glutathione is observed together with the release of thiomalate. The $\mathrm{CH}_{2}$ resonance of cysteinyl residue changes from asymmetric quartet into a multiplet by the proximity of the metal center. The two resonances from the glutamyl residue of glutathione are also affected but to a smaller extent. The spectra 


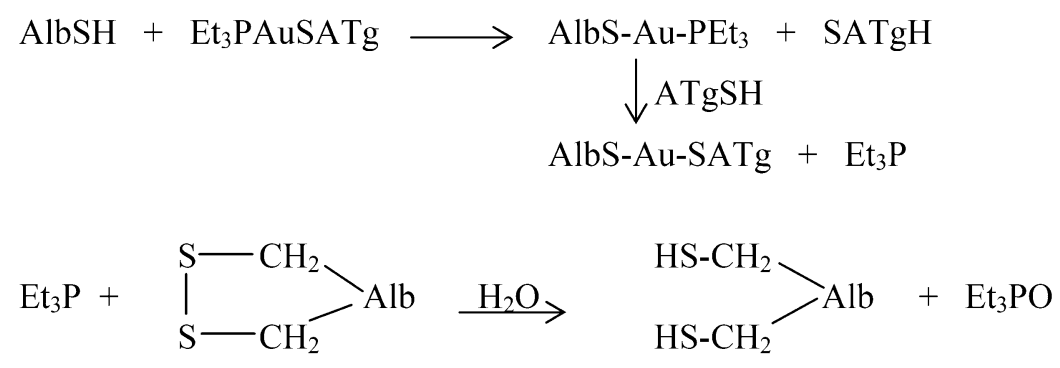

Scheme 1.

of gold titration into red cell lysate were identical to the above pattern. The addition of myocrisin to a suspension of intact erythrocytes produced a different pattern of reactivity. In the ${ }^{1} \mathrm{H}$ NMR, the cysteinyl $\mathrm{CH}_{2}$ resonances responded to the presence of the gold compounds but the glutamyl resonances do not. This shows that a gold-glutathione complex is not forming in the cytosol in an analogous manner to the lysate and the model system. A diminution of cysteinyl $\mathrm{CH}_{2}$ resonance in the ${ }^{1} \mathrm{H}$ NMR independent of glutamyl resonances is normally regarded as characteristic of glutathione oxidation. These observations suggested that myocrisin stimulates oxidation of intracellular glutathione. The rate of transport of myocrisin across the membrane is slow [37]. The reaction of myocrisin with the membrane bound thiol is represented as:

$$
\text { Membrane-SH }+\mathrm{Au}_{8} \mathrm{tm}_{9} \longrightarrow \text { membrane-S-Au } \mathrm{tm}_{8}+\mathrm{tmH} .
$$

It has been assumed that polymeric aurothiomalate coats the surface of red cells and prevents further entry of gold into cells. Consequently, the kinetics of the reaction with glutathione is expected to be slow. However, the response of glutathione to myocrisin in extracellular fluid is rapid suggesting that transport is not required [27]. In similar experiments with the orally active auranofin the cysteinyl $\mathrm{CH}_{2}$ disappears reflecting the ease of entry of this lipophilic drug into the cell and the increased glutathione exchange rate of gold(I) in the presence of the phosphine ligand [27,30].

The exchange reactions of auranofin have been studied extensively using ${ }^{13} \mathrm{C}$ and ${ }^{31} \mathrm{P}$ NMR spectroscopy. ${ }^{31} \mathrm{P}$ NMR is especially invaluable for investigating the behavior of $\mathrm{Et}_{3} \mathrm{P}$ released from auranofin. The most extensively studied metabolic reactions of auranofin ( $\mathrm{Et}_{3} \mathrm{PAuSATg}$ ) are those of serum albumin (AlbSH), the predominant carrier protein for serum gold. Auranofin reacts at Cys-34 of albumin via a ligand exchange reaction that displaces the sulfhydryl group with the formation of AlbS-Au-PEt 3 . Formation of AlbS-Au-PEt 3 species was identified by the appearance of a resonance at $38.8 \mathrm{ppm}$ in the ${ }^{31} \mathrm{P}$ NMR spectra. The similarity of the chemical shift of AlbS-Au-PEt 3 to those of other thiolate adducts, $\mathrm{RS}-\mathrm{Au}-\mathrm{PEt}_{3}$ suggests that auranofin reacts at Cys-34 with the displacement of $\mathrm{ATgS}{ }^{-}$. The free acetylthioglucose liberated from auranofin reacts further with the AlbS-Au- $\mathrm{PEt}_{3}$ and displaces $\mathrm{PEt}_{3}$, which is oxidized to $\mathrm{Et}_{3} \mathrm{PO}$. Oxygen-17 NMR and GC-MS evidence that the principal oxidants are albumin disulfide bonds of albumin, where water is the major source of oxygen, which participates in the reaction [38]. The sequence of reactions can be represented by Scheme 1 [18,39].

The ${ }^{31} \mathrm{P}$ NMR further confirms that $\mathrm{Et}_{3} \mathrm{P}$ is released from albumin bound complex rather from auranofin. It also gives indication about the gold binding at weak binding sites such as histidine and methionine residues [18]. It has also been demonstrated by ${ }^{31} \mathrm{P} N M R$ that $\mathrm{Et}_{3} \mathrm{PAu}^{+}$bound to the weak binding of albumin can be transferred to the stronger binding site AlbS-AuPEt ${ }_{3}$ to form the bis complex, AlbS $\left(\mathrm{AuPEt}_{3}\right)_{2}^{+}[40,41]$. The $\mathrm{Et}_{3} \mathrm{PAu}^{+}$entity is also liable to exchange in the presence of $\mathrm{Me}_{3} \mathrm{PAuX}$ and ${ }^{i-} \mathrm{Pr}_{3} \mathrm{PAuX}[41]$. 
Phosphorus-31 NMR studies of the interaction of various $\mathrm{R}_{3} \mathrm{P}-\mathrm{Au}-\mathrm{SATg}$ complexes with albumin reveal that the rate of phosphine oxidation increases as the affinity of the thiol for gold(I) increases, while the rate decreases as the affinity of phosphine in $\mathrm{R}_{3} \mathrm{P}-\mathrm{Au}-\mathrm{SR}$ increases. In the reaction of $\mathrm{Me}_{3} \mathrm{P}-$ $\mathrm{Au}-\mathrm{SATg}$ with albumin the smaller and less basic $\mathrm{Me}_{3} \mathrm{P}$ is displaced to form the corresponding $\mathrm{Me}_{3} \mathrm{PO}$ more readily than is $\mathrm{Et}_{3} \mathrm{P}$ in $\mathrm{Et}_{3} \mathrm{P}-\mathrm{Au}-\mathrm{SATg}$ [42]. In the reaction of isopropyl analogue of auranofin, the ${ }^{i} \mathrm{Pr}_{3} \mathrm{PO}$ is formed only in small quantity, while the rest of the phosphine is oxidized to ${ }^{i} \operatorname{Pr}_{3} \mathrm{PS}$. The experiment further demonstrates that in contrast the displacement of $\mathrm{Et}_{3} \mathrm{P}$ from $\mathrm{Et}_{3} \mathrm{P}-\mathrm{Au}-\mathrm{SAlb}$ by thiols, cyanide is required to displace ${ }^{i} \mathrm{Pr}_{3} \mathrm{P}$ from ${ }^{i} \mathrm{Pr}_{3} \mathrm{P}-\mathrm{Au}-\mathrm{SAlb}$ [43].

The values of ${ }^{31} \mathrm{P}$ chemical shifts of various species are given in Table 1. In $\mathrm{Et}_{3} \mathrm{P}-\mathrm{Au}-\mathrm{SR}$ complexes, the ${ }^{31} \mathrm{P}$ chemical shifts are correlated directly with the affinity of thiols for gold(I) and inversely with their $\mathrm{pK}_{\mathrm{SH}}$ values. The ability of various thiols to cause $\mathrm{Et}_{3} \mathrm{PO}$ formation from $\mathrm{AlbS}-\mathrm{Au}-\mathrm{PEt}_{3}$ is; AT$\mathrm{gSH}>\mathrm{TgSH}>\mathrm{GSH}$, as expected from their basicity [33]. The correlation of $\delta\left({ }^{31} \mathrm{P}\right)$ and $\mathrm{pK}_{\mathrm{a}}$ values helps to estimate the binding strength of other thiolate ligands. For example the $\delta\left({ }^{31} \mathrm{P}\right)$ for the adduct of hemoglobin with auranofin was observed at $34.0 \mathrm{ppm}$, which suggests the low affinity of hemoglobin towards gold compared to other thiols listed in Table 1. As a result of its low affinity, inter protein gold transfer from $\mathrm{Hb}\left(\mathrm{SAuPEt}_{3}\right)_{2}$ to mercaptalbumin was observed using ${ }^{31} \mathrm{P} \mathrm{NMR}$. As indicated by the ${ }^{31} \mathrm{P}$ NMR chemical shift values (Table 1), glutathione (GSH) is a more favorable binding site in RBC than hemoglobin. GSH does not however compete effectively with serum albumin for gold(I). The high affinity of albumin towards gold compared to hemoglobin and glutathione suggests that the accumulation/transfer of gold metabolites of auranofin in RBC is thermodynamically not favored. The ${ }^{31} \mathrm{P} N M R$ correlation predicted the direction of the inter protein ( $\mathrm{Hb}$ to $\mathrm{Alb}$ ) gold transfer reaction and thus it is helpful in predicting the position of equilibria [25]. The transfer of $\mathrm{Et}_{3} \mathrm{PAu}^{+}$between protein species provide support to the sulfhydral shuttle mechanism for $\mathrm{Et}_{3} \mathrm{PAu}^{+}$transport across the cell membrane.

The ${ }^{31} \mathrm{P}$ NMR spectroscopy was successfully applied to study the mechanism of the reaction of AlbS with auranofin and its analogue, ${ }^{i} \mathrm{Pr}_{3} \mathrm{P}-\mathrm{Au}-\mathrm{SATg}$. The kinetic analysis of the reaction between auranofin and serum albumin shows that the reaction is first order in albumin and zero order with respect to auranofin, with a rate constant, $k_{1}=3.4 \pm 0.3 \times 10^{-2} \mathrm{sec}^{-1}$ for Eq. (2). However, under physiological conditions, where auranofin concentration is low, 10-25 $\mu \mathrm{M}$ ([albumin] $=\sim 400 \mu \mathrm{M}$ ) the reaction is suggested to follow the second order kinetics with a rate constant of $8 \pm 2 \times 10^{2} \mathrm{M}^{-1} \mathrm{~s}^{-1}$ [34]. This high value of rate constant corresponding to a rapid ligand exchange reaction of auranofin with albumin explains the very strong affinity of Cys-34 for gold(I). The ${ }^{1} \mathrm{H}$ NMR study of the reaction of albumin with gold drugs also suggest that Cys-34 is the major binding site of albumin for gold(I) [45]. A multistep mechanism was proposed [34] which can be explained as follow;

$$
\begin{aligned}
& \text { AlbSH } \underset{k_{-1}}{\stackrel{k_{1}}{\leftrightarrows}} * \text { AlbSH, } \\
& \text { *AlbSH }+\mathrm{R}_{3} \text { PAuSATg } \underset{k_{-2}}{\stackrel{k_{2}}{\leftrightarrows}} * \mathrm{AlbSAuPR}_{3}+\mathrm{ATgSH}, \\
& \text { *AlbSAuPR } 3 \underset{k_{-3}}{\stackrel{k_{3}}{\leftrightarrows}} \mathrm{AlbSAuPR}_{3},
\end{aligned}
$$

where ${ }^{*} \mathrm{AlbSH}$ and ${ }^{*} \mathrm{AlbSAuPR}_{3}$ are conformationally altered albumin molecules in which Cys-34 is accessible to other solute molecules. 
Table 1

${ }^{31} \mathrm{P}$ NMR chemical shifts in ppm of various species in methanol (containing buffer) relative to TMP

\begin{tabular}{|c|c|c|}
\hline Species & $\delta^{13} \mathrm{P}$ & Reference \\
\hline$\overline{\mathrm{Et}_{3} \mathrm{PAuCl}}$ & 32.0 & 25,44 \\
\hline$\left(\mathrm{Et}_{3} \mathrm{P}\right)_{2} \mathrm{Au}^{+}$ & 44.0 & $40,41,44$ \\
\hline $\mathrm{Et}_{3} \mathrm{PAuSATg}$ & 36.7 & 18,33 \\
\hline \multicolumn{3}{|l|}{$\left(\mathrm{pK}_{\mathrm{SH}}=6.4\right)$} \\
\hline $\operatorname{AtgS}\left(\mathrm{AuEt}_{3} \mathrm{P}\right)_{2}^{+}$ & $34.7 \& 35.0^{\mathrm{a}}$ & 44 \\
\hline $\mathrm{AlbSAuPEt}_{3}$ & 38.8 & $18,33,40$ \\
\hline \multicolumn{3}{|l|}{$\left(\mathrm{pK}_{\mathrm{SH}}=\sim 5\right)$} \\
\hline $\operatorname{AlbS}\left(\mathrm{AuEt}_{3} \mathrm{P}\right)_{2}^{+}$ & 35.7 & $40,41,44$ \\
\hline $\mathrm{Et}_{3} \mathrm{PAuSTg}$ & 36.3 & 25,33 \\
\hline \multicolumn{3}{|l|}{$\left(\mathrm{pK}_{\mathrm{SH}}=7.6\right)$} \\
\hline $\mathrm{Et}_{3} \mathrm{PAuSGlu}$ & 35.8 & 25,33 \\
\hline \multicolumn{3}{|l|}{$\left(\mathrm{pK}_{\mathrm{SH}}=8.9\right)$} \\
\hline $\mathrm{Hb}\left(\mathrm{SAuEt}_{3} \mathrm{PAu}\right)_{\mathrm{x}}$ & 34.0 & 25 \\
\hline $\mathrm{ErSAuPEt}_{3}$ & 34.6 & 25 \\
\hline \multicolumn{3}{|l|}{$\left(\mathrm{pK}_{\mathrm{SH}}=10.8\right)$} \\
\hline $\mathrm{Me}_{3} \mathrm{PAuSATg}$ & -3.0 & 41,42 \\
\hline $\mathrm{AlbSAuPMe}_{3}$ & -2.3 & 41,42 \\
\hline${ }^{i} \mathrm{Pr}_{3} \mathrm{PAuSATg}$ & 66.0 & 41,43 \\
\hline $\mathrm{AlbSAuP}{ }^{i} \operatorname{Pr}_{3}$ & 68.5 & 41,43 \\
\hline $\mathrm{Et}_{3} \mathrm{PAuCN}$ & 35.4 & 24 \\
\hline $\mathrm{Et}_{3} \mathrm{PO}$ & 58.40 & 8,19 \\
\hline
\end{tabular}

In the crystal structure of albumin, Cys-34 is protected in a crevice, stabilized by in the ionized Cys ${ }^{-}$ form possibly via hydrogen bonding to histidine 39 [46]. A structural change, where it moves to a more solvent exposed position is required when it binds to gold(I) or a disulfide [47]. The conformationally altered albumin species could not be identified by chromatography and the chromatographic methods suggested that the reaction is first order with respect to ${ }^{i} \operatorname{Pr}_{3} \mathrm{P}-\mathrm{Au}-\mathrm{SATg}$. Thus the mechanism of this reaction could not be explained by chromatography and only NMR results describe the most probable mechanism. The rate law corresponding to this mechanism is;

$$
\frac{\mathrm{d}\left[\mathrm{AlbSAuPR}_{3}\right]}{\mathrm{dt}}=\frac{k_{1} k_{2}\left[\mathrm{R}_{3} \mathrm{PAuSATg}\right][\mathrm{AlbSH}]}{k_{-1}+k_{2}\left[\mathrm{R}_{3} \mathrm{PAuSATg}\right]}=k_{\mathrm{obs}}[\mathrm{AlbSH}],
$$

where,

$$
k_{\mathrm{obs}}=\frac{k_{1} k_{2}\left[\mathrm{R}_{3} \mathrm{PAuSATg}\right]}{k_{-1}+k_{2}\left[\mathrm{R}_{3} \mathrm{PAuSATg}\right]} .
$$

Saturation transfer experiments on ${ }^{i} \mathrm{Pr}_{3} \mathrm{P}-\mathrm{Au}-\mathrm{SATg}$ under equilibrium conditions yielded 2 nd order rate constants for both the forward $\left(1.2 \times 10^{2} \mathrm{M}^{-1} \mathrm{~S}^{-1}\right)$ and the reverse $\left(3.9 \times 10 \mathrm{M}^{-1} \mathrm{~S}^{-1}\right)$ directions.

Phosphorus-31 NMR spectroscopy can be used to probe the specific target sites for gold drugs. For example the ${ }^{31} \mathrm{P}$ NMR studies of the $\mathrm{Et}_{3} \mathrm{PAuCl}$ and $\left(\mathrm{Et}_{3} \mathrm{P}\right)_{2} \mathrm{AuCl}$ with human blood demonstrated that 
$\mathrm{Et}_{3} \mathrm{PAuCl}$ reacts with red blood cells binding to thiol sites of glutathione and hemoglobin, whereas $\left(\mathrm{Et}_{3} \mathrm{P}\right)_{2} \mathrm{AuCl}$ reductively attacks $\mathrm{S}-\mathrm{S}$ linkage of plasma albumin (eq.)

$$
\begin{aligned}
& \mathrm{Et}_{3} \mathrm{PAuCl}+\mathrm{RSH} \leftrightarrows \mathrm{Et}_{3} \mathrm{PAuSR}+\mathrm{H}^{+}+\mathrm{Cl}^{-} \\
& \left(\mathrm{Et}_{3} \mathrm{P}\right)_{2} \mathrm{Au}^{+}+\mathrm{RS}-\mathrm{SR}+\mathrm{H}_{2} \mathrm{O} \leftrightarrows \mathrm{Et}_{3} \mathrm{PAu}^{+}+2 \mathrm{RSH}+\mathrm{Et}_{3} \mathrm{PO} \\
& \mathrm{Et}_{3} \mathrm{PAu}^{+}+\mathrm{RSH} \leftrightarrows \mathrm{Et}_{3} \mathrm{PAuSR}+\mathrm{H}^{+}
\end{aligned}
$$

The bis complex accelerates rather than inhibits the SH-SS exchange reactions and therefore are not suitable as antiarthritic agent [48].

\section{Exchange reactions with thiones}

In the interaction of aurothiomalate with red cells, it has been observed that when all glutathione is complexed gold thiomalate reacts with ergothionine, which predominantly occurs in thione form $[27,30]$. This observation suggested that $\mathrm{Au}(\mathrm{I})$ reacts with thiones less strongly than does to thiols. The reaction of thiones such as ergothionine [28], Imt (imidazolidine-2-thione) [49], Diaz (1,3-diazinane-2-thione) [50] and mercaptopurines [51] with (Autm) ${ }_{n}$ usually leads to a ternary complex, [>C=S-Au-tm] without ejecting thiomalate. The excess ligands are in rapid exchange with the bound ligand. A comparison of the ${ }^{13} \mathrm{C}$ chemical shifts of the carbon atom attached to the coordinating sulfur atom of various thione ligands at the $1: 1$ ratio of thione :(Autm) $)_{n}$ is given in Table 2 . It is observed that the thiolated nucleosides bind more strongly than do other thiones with gold(I).

${ }^{13} \mathrm{C}$ and ${ }^{15} \mathrm{~N}$ NMR studies of the interaction of (Autg) ${ }_{n}$ with thiones demonstrate that thiones bind to (Autg) ${ }_{n}$ weakly and (Autg) ${ }_{n}$ polymer does not undergo exchange reactions with thione ligands completely [54]. This reflects that although gold thiolates are polymeric, they have different chemical reactivities. It seems that the $\mathrm{Au}-\mathrm{S}$ bond in (Autg $)_{n}$ is stronger compared to that in (Autm) $)_{n}$. On the other hand, the reactions of thiol $[18,33]$ and $\mathrm{CN}^{-}[31,55]$ result in the loss of polymeric structure, leading to formation of $\left[\mathrm{Au}(\mathrm{SR})_{2}\right]^{-}$and $\left[\mathrm{Au}(\mathrm{CN})_{2}\right]^{-}$(or $[\mathrm{RS}-\mathrm{Au}-\mathrm{CN}]^{-}$) species respectively.

Recently, the reactions of auranofin $\left(\mathrm{Et}_{3}\right.$ PAuSATg) with various thiones have been monitored by ${ }^{13} \mathrm{C}$ and ${ }^{31} \mathrm{P}$ NMR [56,57]. These studies revealed that both $\mathrm{Et}_{3} \mathrm{P}$ and $\mathrm{SATg}^{-}$ligands were replaced by thiones simultaneously from gold(I) in auranofin forming $[>\mathrm{C}=\mathrm{S}-\mathrm{Au}-\mathrm{SATg}]$ and $\left[\mathrm{Et}_{3} \mathrm{P}-\mathrm{Au}-\mathrm{S}=\mathrm{C}<\right]$ type complexes. These ligands are consequently oxidized to $\mathrm{Et}_{3} \mathrm{PO}$ and $(\mathrm{SATg})_{2}$ respectively. Some of the liberated $\mathrm{E}_{3} \mathrm{P}$ also reacts with thiones forming $\mathrm{Et}_{3} \mathrm{P}-\mathrm{S}=\mathrm{C}<$ species. Thus the $\mathrm{Et}_{3} \mathrm{P}$ released from auranofin

Table 2

Difference in the ${ }^{13} \mathrm{C}$ NMR chemical shifts $(\Delta \delta)$ in ppm of the $>\mathrm{C}=\mathrm{S}$ resonance of thione at a $1: 1$ ratio of RS : (Autm $)_{n}$

\begin{tabular}{lccc}
\hline$>\mathrm{C}=\mathrm{S}$ & $\mathrm{pH}$ & $\Delta \delta$ & Reference \\
\hline $\mathrm{Imt}$ & 7.40 & 2.55 & 49 \\
Diaz & 7.40 & 2.05 & 50 \\
Thiourea & 7.0 & 2.6 & 52 \\
Ergothionine & 7.40 & 2.99 & 28 \\
2-Thiouracil & 10.50 & 3.63 & 53 \\
6-MP & 11.45 & 3.40 & 51 \\
6-MPR & 8.67 & 17.66 & 51 \\
2-A-6-MPR & 9.50 & 17.54 & 51 \\
\hline
\end{tabular}




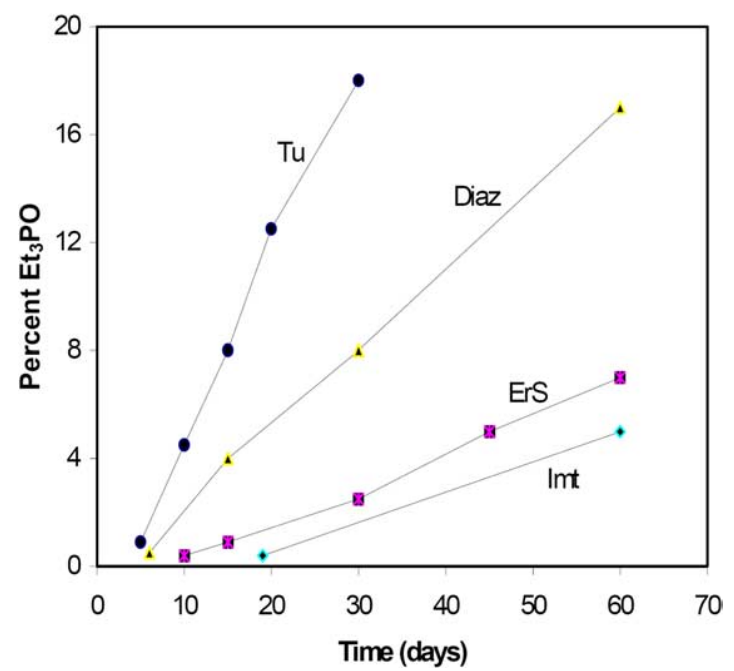

Fig. 3. Rate of formation of $\mathrm{Et}_{3} \mathrm{PO}$ from auranofin with various thiones (the percentage of $\mathrm{Et}_{3} \mathrm{PO}$ was determined by integration of ${ }^{31} \mathrm{P}$ NMR spectra).

can react with the cellular species in addition to its oxidation during exchange reactions in vivo. The $\mathrm{Et}_{3} \mathrm{PO}$ resonance in ${ }^{31} \mathrm{P}$ NMR is observed after several days, which confirms the slower rate of these exchange reactions. The reactions of thiols are comparatively faster. The resonances for $[>\mathrm{C}=\mathrm{S}-\mathrm{Au}-\mathrm{SATg}]$ and $(\mathrm{SATg})_{2}$ species also appeared in ${ }^{13} \mathrm{C}$ NMR after several days of addition of thiones to auranofin showing that these exchange reactions are very slow. The rate of reaction of auranofin towards thiones at $298 \mathrm{~K}$ is found to be approximately $1 \times 10^{-9} \mathrm{M} / \mathrm{S}$. A comparison of the rate of formation of $\mathrm{Et}_{3} \mathrm{PO}$ from auranofin with various thiones is shown in Fig. 3. Thus among thiones the order of reactivity towards auranofin is $\mathrm{Tu}>\mathrm{Diaz}>\mathrm{ErS}>\mathrm{Imt}$. Since thiones can replace both ligands from auranofin, there is a possibility that they can undergo exchange reactions with the adducts formed between gold drugs and cellular thiols like glutathione.

\section{Exchange reactions with disulfides}

With its chain structure (Autm) $)_{n}$ may have a capacity, to react with disulfides and diselenides in addition to thiols and selenols. Since on binding to (Autm) ${ }_{n}$, the disulfide (S-S) linkage should be reduced to the thiolate form, therefore redox, instead of simple exchange reactions are expected to occur in these interactions. In the exchange reactions of (Autm $)_{n}$ with disulfides, different kinds of exchange processes were observed for two different disulfides [58]. In the case of Ellmans reagent, the proton NMR revealed two sets of signals for the ES moiety, indicating formation of two new products. These resonances were assigned to a mixed disulfide (ES-tm) and a polymer capped by ES moieties. The formation of new species was confirmed by Raman spectroscopy. This was explained by the following equation;

$$
\text { 2ESSE Tm- }\left(\mathrm{Au}_{8} \mathrm{tm}_{7}\right)-\mathrm{Tm} \longrightarrow \mathrm{ES}-\mathrm{Au}_{8} \mathrm{tm}_{7}-\mathrm{ES}+2 \mathrm{EStm} .
$$

The overall exchange process can be represented as:

$$
2 \mathrm{Au}_{8} \mathrm{tm}_{9}+17 \mathrm{ESSE} \longrightarrow 2(\mathrm{AuES})_{8}+18 \mathrm{ES}-\mathrm{tm} .
$$


In the case of lipoic acid, a slow direct reaction was observed, producing dithiomalate $(\mathrm{tm})_{2}$ as end product and no mixed disulfide was detected. The $(\mathrm{tm})_{2}$ resonances were observed after one week in ${ }^{1} \mathrm{H}$ NMR showing that the exchange process was very slow.

$$
2 \mathrm{Au}_{8} \mathrm{tm}_{9}+16 \text { Lipoic acid } \longrightarrow 2(\mathrm{Au}-\text { Lipoic })_{8}+9 \mathrm{tm}_{2} \text {. }
$$

Myocrisin is also known to react with the disulfide sites on exofacial surface of the membrane proteins. The reaction occurs primarily by exchange at the terminal (Autm) $)_{n}$ moieties.

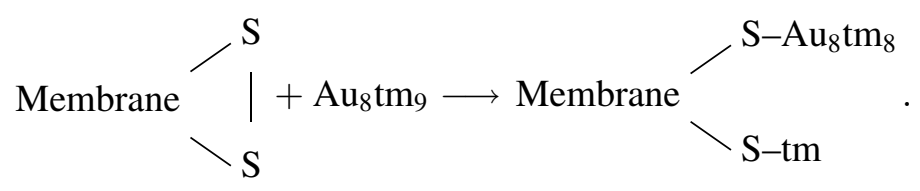

This exchange process does not entail any redox behavior on the part of the sulfhydryl functions (glutathione) in the membrane proteins [27].

Auranofin is also known to bind with the disulfide sites of albumin as described by Eq. (14), but there is no systematic study describing the behavior of auranofin towards disulfides.

$$
\mathrm{AlbSSR}+\mathrm{Et}_{3} \mathrm{PAuSATg} \leftrightarrows \mathrm{AlbSSR}_{-} \mathrm{Et}_{3} \mathrm{PAuSATg}
$$

The AlbSSR-Et ${ }_{3}$ PAuSATg complex is weakly bound and readily dissociates during separation by conventional gel chromatography [34].

Phosphine gold(I) thiolate complexes react with disulfides to undergo a thiolate/disulfide exchange, as described by Eqs (15) and (16) for mononuclear and a dinuclear complex respectively [59].

$$
\begin{aligned}
& \mathrm{Ph}_{3} \mathrm{PAu}\left(\mathrm{SC}_{6} \mathrm{H}_{4} \mathrm{CH}_{3}\right)+\left(\mathrm{SC}_{6} \mathrm{H}_{4} \mathrm{Cl}\right)_{2} \longrightarrow \mathrm{Ph}_{3} \mathrm{PAu}\left(\mathrm{SC}_{6} \mathrm{H}_{4} \mathrm{Cl}\right)+\left(\mathrm{C}_{6} \mathrm{H}_{4} \mathrm{ClS}\right)\left(\mathrm{SC}_{6} \mathrm{H}_{4} \mathrm{CH}_{3}\right), \\
&(\mathrm{dppm}) \mathrm{Au}_{2}\left(\mathrm{SC}_{6} \mathrm{H}_{4} \mathrm{CH}_{3}\right)_{2}\left(\mathrm{SC}_{6} \mathrm{H}_{4} \mathrm{Cl}\right)_{2} \longrightarrow \longrightarrow \\
&(\mathrm{dppm}) \mathrm{Au}_{2}\left(\mathrm{SC}_{6} \mathrm{H}_{4} \mathrm{CH}_{3}\right)\left(\mathrm{SC}_{6} \mathrm{H}_{4} \mathrm{Cl}\right)+\left(\mathrm{C}_{6} \mathrm{H}_{4} \mathrm{ClS}\right)\left(\mathrm{SC}_{6} \mathrm{H}_{4} \mathrm{CH}_{3}\right) .
\end{aligned}
$$

Proton NMR confirms that the reaction proceeds in a stepwise fashion in which the unsymmetrical disulfide forms first followed by the formation of the symmetrical disulfide. Variable temperature ${ }^{31} \mathrm{P} N M R$ experiments suggest that $\mathrm{Au}-\mathrm{Au}$ bonding in gold(I) thiolate clusters influences the reactivity towards disulfides [60]. The cluster complexes undergo thiolate/disulfide exchange reactions more rapidly than monomeric complexes [59].

\section{Gold-cyanide metabolites}

The reaction of cyanide with gold are of therapeutic interest because the physiological distribution of gold(I) is believed to be affected by the cyanide present in the blood. Cyanide is produced naturally in the body by oxidation of $\mathrm{SCN}^{-}$by the enzyme myeloperoxidase in polymorphonuclear leukocytes (PMN) $[61,62] .\left[\mathrm{Au}(\mathrm{CN})_{2}\right]^{-}$has been identified as a common metabolite of the gold drugs in the blood and urine of chrysotherapy patients [63]. The reactions of gold drugs and their metabolites with cyanide lead to the formation of intermediates, $[\mathrm{RSAuCN}]^{-}$and $\left[\mathrm{Et}_{3} \mathrm{PAuCN}\right]$, which undergo disproportionation generating 
$\left[\mathrm{Au}(\mathrm{CN})_{2}\right]^{-}$that is readily taken up by red blood cells according to Eq. (1) $[24,31,61,62,64]$. Graham et al. investigated the effect of cyanide on (Autm) $)_{n}$ activation. It was observed that the cellular uptake of gold from (Autm) $)_{n}$ was slow in the absence of cyanide. Cyanide markedly increased the uptake of gold by red blood cells, $21.1 \%$ after incubation for 24 hours [65]. Tobacco smoking is known to increase the concentrations of gold in red blood cells in patients treated with (Autm) ${ }_{n}[66,67]$. Cyanide acts as a shuttle to carry gold into red blood cells, because of inhalation of HCN from tobacco smoke [64].

Proton and ${ }^{13} \mathrm{C}$ CNMR spectroscopic investigations of the interaction of gold(I) thiolates with $\mathrm{CN}^{-}$ shows that $\mathrm{CN}^{-}$binds to gold(I) releasing thiols as free ligands in solution $[31,36,55,68]$. The formation of $\left[\mathrm{Au}(\mathrm{CN})_{2}\right]^{-}$is the result of following equilibrium;

$$
2[\mathrm{tm}-\mathrm{Au}-\mathrm{CN}] \leftrightarrows\left[\mathrm{Au}(\mathrm{tm})_{2}\right]^{-}+\left[\mathrm{Au}(\mathrm{CN})_{2}\right]^{-}
$$

In the case of auranofin ( $\mathrm{Et}_{3} \mathrm{PAuSATg}$ ), both the ligands can be replaced by cyanide thereby generating $\left[\mathrm{Au}(\mathrm{CN})_{2}\right]^{-}[56]$. But no systematic study on the reaction of auranofin with cyanide has been carried out. However, the reaction of AlbS-Au- $\mathrm{PEt}_{3}$ (auranofin is metabolized to AlbS-Au-PEt 3 ) with $\mathrm{HCN}$ has been studied using ${ }^{13} \mathrm{C}$ and ${ }^{31} \mathrm{P}$ NMR. The reaction of $\mathrm{HCN}$ with $\mathrm{AlbS}-\mathrm{Au}-\mathrm{PEt}_{3}$ yields irreversibly formed products, $\mathrm{Et}_{3} \mathrm{PO},\left[\mathrm{Au}(\mathrm{CN})_{2}\right]^{-}$and $[\mathrm{AlbSAuCN}]^{-}$. $\mathrm{Et}_{3} \mathrm{PAuCN}$ was also observed as a transient equilibrium product (Eq. (19)) [24]:

$$
\begin{aligned}
& \mathrm{AlbS}-\mathrm{Au}-\mathrm{PEt}_{3}+\mathrm{HCN} \leftrightarrows \mathrm{AlbSAuCN}^{-}+\mathrm{H}^{+}+\mathrm{Et}_{3} \mathrm{P} \\
& \stackrel{\mathrm{Et}_{3} \mathrm{PO}}{\longrightarrow}
\end{aligned}
$$

$$
\mathrm{AlbS}-\mathrm{Au}-\mathrm{PEt}_{3}+\mathrm{HCN} \leftrightarrows \mathrm{Et}_{3} \mathrm{PAuCN}+\mathrm{AlbSH}
$$

Several studies describe the formation of $\left[\mathrm{Au}(\mathrm{CN})_{2}\right]^{-}$by disproportionation of $\mathrm{L}-\mathrm{Au}-\mathrm{CN}$ complexes in solution [69-74].

$$
2[\mathrm{~L}-\mathrm{Au}-\mathrm{CN}] \leftrightarrows\left[\mathrm{AuL}_{2}\right]^{+}+\left[\mathrm{Au}(\mathrm{CN})_{2}\right]^{-}
$$

The very large formation constant of $\left[\mathrm{Au}(\mathrm{CN})_{2}\right]^{-}(\log \beta=36.6)$ [75] is believed to drive the reaction in the forward direction generating $\left[\mathrm{Au}(\mathrm{CN})_{2}\right]^{-}$. These reactions can easily be monitored by ${ }^{13} \mathrm{C} \mathrm{NMR}$. However, for $\mathrm{R}_{3} \mathrm{PAuCN}$ complexes ${ }^{31} \mathrm{P}$ NMR has been successfully applied to study these reactions [70-72]. In the ${ }^{13} \mathrm{C}$ NMR spectra of such complexes two resonances are observed for $\mathrm{CN}$ carbon, corresponding to $\mathrm{LAuCN}$ and $\left[\mathrm{Au}(\mathrm{CN})_{2}\right]^{-}$species. When ${ }^{13} \mathrm{C}$ and ${ }^{15} \mathrm{~N}$ labeled $\mathrm{CN}$ was used the $\left[\mathrm{Au}(\mathrm{CN})_{2}\right]^{-}$ resonance appeared as triplet and the resonance for $\mathrm{LAuCN}$ was a doublet. A similar observation was recorded in the ${ }^{15} \mathrm{~N}$ NMR $[69,72-74]$.

For cyano(phosphine)gold(I) complexes the ${ }^{31} \mathrm{P}$ NMR spectra revealed two signals, one each from $\mathrm{R}_{3} \mathrm{PAuCN}$ and $\left[\mathrm{Au}\left(\mathrm{R}_{3} \mathrm{P}\right)_{2}\right]^{+}$species. The ${ }^{13} \mathrm{C}$ and ${ }^{15} \mathrm{~N}$ NMR spectra of $\mathrm{R}_{3} \mathrm{PAuCN}$ complexes also showed two resonances in the low field region corresponding to Eq. (13). The ${ }^{13} \mathrm{C}$ and ${ }^{15} \mathrm{~N} N M R$ chemical shifts were found to have opposite dependence on the basicity of phosphines in $\mathrm{R}_{3} \mathrm{PAuCN}$ complexes. The ${ }^{15} \mathrm{~N}$ resonances shifted upfield, while the ${ }^{13} \mathrm{C}$ resonances shifted downfield with increase in the basicity of the phosphine. This opposite behavior can be explained on the basis of back bonding between gold(I) and cyanide. The donation of electron density from electron rich metal center to cyanide increases the double bond character of the $\mathrm{Au}-\mathrm{C}$ bond resulting in a deshielding effect on carbon. Similarly, the reduction in the $\mathrm{C}-\mathrm{N}$ bond order in the $\pi$ species is accompanied by an upfield shift in ${ }^{15} \mathrm{~N}$ NMR [72]. 
Similar to $\mathrm{R}_{3} \mathrm{PAuCN}$ complexes, the ligand scrambling reactions were also investigated in [thioneAuCN] and [selenoneAuCN] complexes. Both types of the complexes yielded two resonances for the $\mathrm{CN}$ group in ${ }^{13} \mathrm{C}$ and ${ }^{15} \mathrm{~N}$ NMR, consistent with the scrambling equilibria given in Eq. (20). The equilibrium constants were calculated using relative intensities of $\mathrm{CN}$ resonances in LAuCN and $\left[\mathrm{Au}(\mathrm{CN})_{2}\right]^{-}$complexes in ${ }^{13} \mathrm{C} \mathrm{NMR}$, which gave the relative concentration of all three species $[73,74]$.

Aurocyanide $\left(\left[\mathrm{Au}(\mathrm{CN})_{2}\right]^{-}\right)$is rapidly taken up by polymorphonuclear leukocytes, and red blood cells and could affect the function of these cells [76]. In RBCs, hemoglobin and glutathione are the main protein target for gold. The experiments showed that most of the gold in RBCs is bound to glutathione. Although, the concentration of cyanide is very low in RBCs $(0.3-1 \mu \mathrm{M})$ [77,78], there is a high formation constant between cyanide and gold(I), $\sim 10^{39}[79]$ and therefore bis(glutathione)gold(I) and dicyanogold(I) are likely to be found in RBCs. The mechanism by which $\left[\mathrm{Au}(\mathrm{CN})_{2}\right]^{-}$is transported through the cell membrane is still a subject of current research $[62,64,80]$. However, the most convincing mechanism is the one in which gold(I) complexes undergo ligand exchange reactions to bind to sulfhydryl groups immobilized on or in the membrane. A series of such exchange reactions then passes the gold across the membrane and into the cells, where it may react with molecules containing sulfhydryl groups such as glutathione [81]. The formation of [RSAuCN $]^{-}$has also been reported as partially displacing $\mathrm{CN}^{-}$from $\left[\mathrm{Au}(\mathrm{CN})_{2}\right]^{-}$with thiols such as cysteine and glutathione in aqueous solution, although the formation constant of $[\mathrm{RSAuCN}]^{-}$is less than $\left[\mathrm{Au}(\mathrm{CN})_{2}\right]^{-}[82]$.

$$
\left[\mathrm{Au}(\mathrm{CN})_{2}\right]^{-}+\mathrm{RSH} \rightarrow[\mathrm{RSAuCN}]^{-}+\mathrm{HCN} .
$$

When cyanide in $\left[\mathrm{Au}(\mathrm{CN})_{2}\right]^{-}$is replaced by another group, the stability constant of the resulting complex significantly decreases, for example; $[\mathrm{Au}(\mathrm{CN}) \mathrm{I}]^{-}(\log \beta=28.9),[\mathrm{Au}(\mathrm{CN})(\mathrm{mpt})](\log \beta=30.9)$, $\left[\mathrm{Au}(\mathrm{mpt})_{2}\right]^{+}(\log \beta=17.9)$ [83].

${ }^{13} \mathrm{C}$ NMR studies of the reaction of bovine serum albumin (BSA) with $\left[\mathrm{Au}(\mathrm{CN})_{2}\right]^{-}$suggest the formation of BSA- $\left[\mathrm{Au}(\mathrm{CN})_{2}\right]^{-}$adducts, unlike gold drugs which undergo ligand exchange reactions preferentially at cysteine.

$$
\mathrm{BSA}+\left[\mathrm{Au}(\mathrm{CN})_{2}^{-}\right]_{n} \leftrightarrows \mathrm{BSA} \cdot n\left[\mathrm{Au}(\mathrm{CN})_{2}^{-}\right]
$$

The equilibrium binding constant at $\mathrm{pH} 7.4$ is $K_{1}=5.5( \pm 1.1) \times 10^{4}$ [64]. The easily reversed association of intact dicyanoaurate(I) with albumin and the unfavorable reaction at cysteine-34 are consistent with the proposed roles of $\left[\mathrm{Au}(\mathrm{CN})_{2}\right]^{-}$as, a cellularly accumulated metabolite [65] and a urinary excretion product [63].

$\left[\mathrm{Au}(\mathrm{CN})_{2}\right]^{-}$may undergo oxidation by $\mathrm{OCl}^{-}$generating gold(III) metabolites [80]. The reactions of $\left[\mathrm{Au}(\mathrm{CN})_{2}\right]^{-}$with $\mathrm{OCl}^{-}$have been studied by ${ }^{13} \mathrm{C} \mathrm{NMR}$. The reversible, $\mathrm{pH}$-dependent changes occurred by the oxidation of $\left[\mathrm{Au}(\mathrm{CN})_{2}\right]^{-}$can be described by Eqs (23) and (24):

$$
\begin{aligned}
& {\left[\mathrm{Au}(\mathrm{CN})_{2}\right]^{-}+\mathrm{OCl}^{-} \rightarrow\left[\mathrm{Au}(\mathrm{CN})_{2} \mathrm{X}_{2}\right]^{-} \quad\left(\mathrm{X}=\mathrm{OH}^{-}, \mathrm{Cl}^{-}\right),} \\
& {\left[\mathrm{Au}(\mathrm{CN})_{2} \mathrm{Cl}_{2}\right]^{-} \underset{\mathrm{H}^{+}}{\stackrel{\mathrm{OH}^{-}}{\leftrightarrows}}\left[\mathrm{Au}(\mathrm{CN})_{2}(\mathrm{OH}) \mathrm{Cl}\right]^{-} \underset{\mathrm{H}^{+}}{\stackrel{\mathrm{OH}^{-}}{\leftrightarrows}}\left[\mathrm{Au}(\mathrm{CN})_{2}(\mathrm{OH})_{2}\right]^{-} .}
\end{aligned}
$$

On addition of hypochlorite, the initial $156 \mathrm{ppm}$ of $\left[\mathrm{Au}(\mathrm{CN})_{2}\right]^{-}$was replaced by resonances at $121.0\left\{\left[\mathrm{Au}(\mathrm{CN})_{2}(\mathrm{OH}) \mathrm{Cl}\right]^{-}\right\} \mathrm{ppm}$ and then by $122.7 \mathrm{ppm}\left\{\left[\mathrm{Au}(\mathrm{CN})_{2}(\mathrm{OH})_{2}\right]^{-}\right\}$, as increasing amounts of $\mathrm{OCl}^{-}$were added to the solution. These chemical shift changes towards the chemical shift of 
$\left[\mathrm{Au}(\mathrm{CN})_{4}\right]^{-}\left(\delta_{\mathrm{C}}=106 \mathrm{ppm}\right)$ are consistent with the direction of the gold(I) to gold(III). The transformation of the species resonating at $121 \mathrm{ppm}$, to the one resonating at $122.7 \mathrm{ppm}$ is associated with a ligand exchange reaction (Eq. (24)). Additional hydroxide is also generated according to the half reaction for reduction of the hypochlorite ion, Eq. (25):

$$
\mathrm{OCl}^{-}+\mathrm{H}_{2} \mathrm{O}+2 \mathrm{e}^{-}=2 \mathrm{OH}^{-}+\mathrm{Cl}^{-} \text {. }
$$

When a solution exhibiting only the $122.7 \mathrm{ppm}$ band $\left\{\right.$ due to $\left[\mathrm{Au}(\mathrm{CN})_{2}(\mathrm{OH})_{2}\right]^{-}$\}, was adjusted to $\mathrm{pH}$ 2 with $\mathrm{HCl}$, a new resonance appeared at $119 \mathrm{ppm}$ and was assigned to $\left[\mathrm{Au}(\mathrm{CN})_{2} \mathrm{Cl}_{2}\right]^{-}$. Chloride was completely replaced by cyanide on its further addition. The reaction was anticipated to proceed through $\left[\mathrm{Au}(\mathrm{CN})_{3} \mathrm{Cl}\right]^{-}$to $\left[\mathrm{Au}(\mathrm{CN})_{4}\right]^{-}[80]$.

It was found that the tetracyanoaurate complex, $\left[\mathrm{Au}(\mathrm{CN})_{4}\right]^{-}$could undergo reduction with glutathione $(\mathrm{GSH})$ releasing $\left[\mathrm{Au}(\mathrm{CN})_{2}\right]^{-}$. It was observed in ${ }^{13} \mathrm{C}$ NMR that the resonances due to the starting material $\left[\mathrm{Au}(\mathrm{CN})_{4}\right]^{-}(106 \mathrm{ppm})$ and the final product $\left[\mathrm{Au}(\mathrm{CN})_{2}\right]^{-}(156 \mathrm{ppm})$ are present in addition to the intermediates. The reduction of $\left[\mathrm{Au}(\mathrm{CN})_{4}\right]^{-}$occurs according to Eq. (26):

$$
\left[\mathrm{Au}(\mathrm{CN})_{4}\right]^{-}+2 \mathrm{GSH} \rightarrow\left[\mathrm{Au}(\mathrm{CN})_{2}\right]^{-}+2 \mathrm{HCN}+2 \mathrm{GSSG} .
$$

This oxidation and reduction process demonstrates that there is a potential redox cycle involving dicyanoaurate(I) and di- or tetra-cyanoaurate(III) species that could be established in vivo during chrysotherapy when macrophages are stimulated to undergo the oxidative burst [80].

\section{NMR studies of antitumor gold complexes}

Both gold(I) and gold(III) coordination compounds exhibit cytotoxic properties towards several tumor cells and both types of complexes are also effective on cells resistant to cisplatin [7-9]. NMR spectroscopy is also a useful tool to study the interaction of antitumor phosphine gold(I) complexes such as $\left[\mathrm{Au}(\mathrm{dppe})_{2}\right] \mathrm{Cl}$ (dppe $=1,2$-bis(diphenyphosphino)ethane). The effect of $\left[\mathrm{Au}(\mathrm{dppe})_{2}\right] \mathrm{Cl}$ on the metabolism of L1210 leukemia cells extracts was investigated by ${ }^{1} \mathrm{H}$ and ${ }^{31} \mathrm{P}$ NMR. It has been observed that $\left[\mathrm{Au}(\mathrm{dppe})_{2}\right] \mathrm{Cl}$ causes an increase in the lactate levels and accumulation of amino acids, suggesting a drug induced increase in the rate of glycolysis and inhibition of protein synthesis [84]. The reactions of $\left[\mathrm{Au}(\mathrm{dppe})_{2}\right] \mathrm{Cl}$ with human blood plasma, red blood cells have been monitored by ${ }^{1} \mathrm{H}$ and ${ }^{31} \mathrm{P}$ NMR [85]. ${ }^{31} \mathrm{P}$ NMR studies suggest that some $\left[\mathrm{Au}(\mathrm{dppe})_{2}\right]^{+}$is transferred from plasma to red blood cells with a half life of about $2 \mathrm{hrs}$ at $25^{\circ} \mathrm{C}$. The rate of uptake of $\left[\mathrm{Au}(\mathrm{dppe})_{2}\right] \mathrm{Cl}$ from plasma to red cells was evaluated by monitoring the change in intensity of the $\left[\mathrm{Au}(\mathrm{dppe})_{2}\right]^{+}$-phospholipid ${ }^{31} \mathrm{P}$ resonances with time. NMR results suggested that nearly half of the $\left[\mathrm{Au}(\mathrm{dppe})_{2}\right]^{+}$added to plasma was transferred to red cells. The complex binds within the cell membrane and consequently its mobility is reduced resulting in broadening of ${ }^{31} \mathrm{P}$ resonances. Although thiols exchange reactions play a major role in the metabolism of auranofin both in blood plasma and in cells, the complex $\left[\mathrm{Au}(\mathrm{dppe})_{2}\right]^{+}$did not affect the ${ }^{1} \mathrm{H} \mathrm{NMR}$ resonances of intracellular GSH consistent with its low reactivity towards thiols in model systems [85]. ${ }^{31} \mathrm{P}$ NMR studies have also shown that $\left[\mathrm{Au}(\mathrm{dppe})_{2}\right]^{+}$(unlike auranofin) remains essentially intact in human plasma and does not react significantly with glutathione or albumin [86]. This may allow it to reach intracellular target sites, which are inaccessible to auranofin and contribute to its broader spectrum of antitumor activity. Being structurally different, the linear two coordinate and tetrahedral gold(I) 
phosphine complexes may follow different mechanisms. Reactions with sulfhydryl groups are likely to be involved for auranofin and $\mathrm{Et}_{3} \mathrm{PAuCl}$, whereas lipophilic cationic properties of $\left[\mathrm{Au}(\mathrm{dppe})_{2}\right] \mathrm{Cl}$ and [Au(dpype $\left.)_{2}\right] \mathrm{Cl}$ may be important [9].

${ }^{31} \mathrm{P}$ NMR studies of tetrahedral bisphosphine gold(I) complexes with pyridyl substituents $(\mathrm{R}=$ 2-pyridyl/4-pyridyl in Fig. 1) have shown that these are stable for at least $30 \mathrm{hrs}$ when incubated in blood plasma at $37^{\circ} \mathrm{C}$. Whereas the 2-pyridyl complex partitions between plasma and the RBCs, the 4-pyridyl complex (which has higher solubility) is retained in the plasma as evidenced by ${ }^{31} \mathrm{P}$ NMR [87].

For linear digold bis phosphine complexes XAu(dppe)AuX (which are cytotoxic against a wide range of tumors [88]), ${ }^{31} \mathrm{P}$ NMR studies show that thiols induce conversion of the linear complexes in to tetrahedral complex, $\left[\mathrm{Au}(\mathrm{dppe})_{2}\right]^{+}$and this reaction also occurs in blood plasma. The spectrum of antitumor activity of GS-Au(dppe)Au-SG (GS = glutathione) is similar to that of $\left[\mathrm{Au}(\mathrm{dppe})_{2}\right]^{+}$, which is the ring closed product being the major metabolite of the bridged digold complex in vivo [89]. The complex $\left(\mathrm{Ph}_{3} \mathrm{P}\right) \mathrm{Au}(\mathrm{dppp}) \mathrm{Cl}$ is also known to undergo disproportionation giving the $\left[\mathrm{Au}(\mathrm{dppp})_{2}\right]^{+}$complex [90].

\section{Conclusions}

NMR spectroscopy is found to be a useful technique to observe the exchange reactions of gold drugs even in the complex biological media and allows simultaneous detection of many metabolites involved in different metabolic pathways. For gold(I) phosphine drugs, ${ }^{31} \mathrm{P}$ NMR is useful for probing the ligand exchange reactions and the possible cellular target sites. The kinetics of ligand exchange reactions still requires further details. Cyanide plays a key role in the metabolism of gold drugs and $\left[\mathrm{Au}(\mathrm{CN})_{2}\right]^{-}$has been identified as common metabolite. The reactions of cyanide are successfully monitored by ${ }^{13} \mathrm{C} N \mathrm{NR}$ because of the appearances of sharp $\mathrm{CN}$ resonances in the region of 140-160 ppm. The possible role of thiocyanate in the transport of gold(I) needs to be explored. Ligand exchange reactions of $\left[\mathrm{Au}(\mathrm{CN})_{2}\right]^{-}$ with sulfhydryl groups provide a possible mechanism by which $\left[\mathrm{Au}(\mathrm{CN})_{2}\right]^{-}$is transported across the cell membrane. Similar to the oxidation of $\mathrm{OCl}^{-}$, oxidative addition of $\left[\mathrm{Au}(\mathrm{CN})_{2}\right]^{-}$with other oxidizing agents like disulfides and $\mathrm{H}_{2} \mathrm{O}_{2}$ can provide a good comparison. Further studies are required to explain the formation of gold(III) metabolites. For antitumor gold complexes, there is a need to study the interactions between gold complexes and mitochondrial enzymes and other cellular targets that could lead to cell death. The present study would enhance our understanding of the reaction between gold(I) drugs and cellular species, which in turn helps to understand the mechanism of action of these drugs.

\section{Acknowledgements}

Most of the work reviewed here was carried out at the Department of Chemistry, King Fahd University of Petroleum \& Minerals, Dhahran, Saudi Arabia and we are grateful for all the support provided by the Research Committee of the University.

\section{References}

[1] C.F. Shaw III, Chem. Rev. 99 (1999), 2589.

[2] S.L. Best and P.J. Sadler, Gold Bulletin 29 (1996), 87.

[3] S. Ahmad, A.A. Isab, S. Ali and A.R. Al-Arfaj, Polyhedron 25 (2006), 1633.

[4] T.M. Simon, D.H. Kunishima, G.J. Vibert and A. Lorber, Cancer Res. 41 (1981), 94. 
[5] S.J. Berners-Price, C.K. Mirabelli, R.K. Johnson, M.R. Mattern, F.L. McCabe, L.F. Faucette, C.M. Sung, S.M. Mong, P.J. Sadler and S.T. Crooke, Cancer Res. 46 (1986), 5486.

[6] S.J. Berners-Price, G.R. Girard, D.T. Hill, B.M. Sutton, P.S. Jarrett, L.F. Faucette, R.K. Johnson, C.K. Mirabelli and P.J. Sadler, J. Med. Chem. 33 (1990), 1386.

[7] G. Marcon, S. Carotti, M. Coronnello, L. Messori, E. Mini, P. Orioli, T. Mazzei, M.A. Cinellu and G. Minghetti, J. Med. Chem. 45 (2002), 1672.

[8] M.J. Mckeage, L. Maharaj and S.J. Berners-Price, Coord. Chem. Rev. 232 (2002), 127.

[9] M.P. Rigobello, L. Messori, G. Marcon, M.A. Cinellu, M. Bragadin, A. Folda, G. Scutari and A. Bindoli, J. Inorg. Biochem. 98 (2004), 1634.

[10] S.J. Lippard, Platinum, Gold and Other Metal Chemotherapeutic Agents, ACS Symposium Series, Vol. 209, 1983, p. 356.

[11] D.T. Hill and B.M. Sutton, Cryst. Stuct. Commun. 9 (1980), 679.

[12] R. Bau, J. Am. Chem. Soc. 120 (1998), 9380.

[13] R.C. Elder, K. Ludwig, J.N. Cooper and M.K. Eidness, J. Am. Chem. Soc. 107 (1985), 5024.

[14] D.T. Hill, B.M. Sutton, A.A. Isab, M.T. Razi, P.J. Sadler, J.M. Trooster and G.M. Callis, Inorg. Chem. 22 (1983), 2936.

[15] A.A. Isab and P.J. Sadler, J. Chem. Soc., Dalton Trans. (1981), 1657.

[16] P.J. Sadler, Structure and Bonding 29 (1976), 171.

[17] A.A. Isab and P.J. Sadler, J. Chem. Soc., Dalton Trans. (1982), 135.

[18] M.T. Coffer, C.F. Shaw III, M.K. Eidsness, J.W. Watkins and R.C. Elder, Inorg. Chem. 25 (1986), 333.

[19] D.J. Ecker, J.C. Hemple, B.M. Sutton, R. Krisch and S.T. Crook, Inorg. Chem. 25 (1986), 3139.

[20] C.F. Shaw III, A.A. Isab, M.T. Coffer and C.K. Mirabelli, Biochem. Pharmacol. 40 (1990), 1227.

[21] R.C. Elder, Chem. Rev. 87 (1987), 1027.

[22] A.A. Isab, Transition Met. Chem. 19 (1994), 595.

[23] A.P. Intoccia, T.L. Flanagan, D.T. Walz, L. Gutzait, J.E. Swagzdis, J. Flagillano Jr, B.Y. Hwang, R.H. Dewey and H. Noguchi, in: Bioinorg. Chem. of Gold Coord. Comp., B.M. Sutton, ed., Smith Kline and French Laboratories, Philadelphia, 1983, p. 21.

[24] A.A. Isab, A.L. Hormann, M.T. Coffer and C.F. Shaw III, J. Amer. Chem. Soc. 110 (1988), 3278 and references therein.

[25] C.F. Shaw III, M.T. Coffer, J. Klingbeil and C.K. Mirabelli, J. Am. Chem. Soc. 110 (1988), 729.

[26] D.H. Brown, G. McKlinlay and W.E. Smith, J. Chem. Soc., Dalton Trans. (1977), 1874.

[27] W.E. Smith, J. Reglinski, S. Hoey, D.H. Brown and R.D. Sturrock, Inorg. Chem. 29 (1990), 5190.

[28] A.A. Isab, J. Inorg. Biochem. 45 (1992), 261.

[29] S.J. Berners-Price and P.J. Sadler, Coord. Chem. Rev. 151 (1996), 1.

[30] G. Otiko, M.T. Razi, P.J. Sadler, A.A. Isab and D.L. Rabenstein, J. Inorg. Biochem. 19 (1983), 227.

[31] G.G. Graham, J.R. Bales, M.C. Gtootveld and P.J. Sadler, J. Inorg. Biochem. 25 (1985), 163.

[32] A.A. Isab, I.H. Ghazi, M.I.M. Wazeer and H.P. Perzanowski, J. Inorg. Biochem. 50 (1993), 299.

[33] M.T. Coffer, C.F. ShawIII, A.L. Horman, C.K. Mirabelli and S.T. Crooke, J. Inorg. Biochem. 30 (1987), 177.

[34] J.R. Roberts, J. Xaio, B. Schliesman, D.J. Parsons and C.F. Shaw III, Inorg. Chem. 35 (1996), 424.

[35] C.F. Shaw III, J. Eldridge and M.P. Cancro, J. Inorg. Biochem. 14 (1981), 267.

[36] A.A. Isab, I. Ghazi and A.R. Al-Arfaj, J. Chem. Soc. Dalton Trans. (1993), 841.

[37] D. Lewis, H.A. Capell and W.E. Smith, J. Rheumatol. 11 (1984), 111.

[38] A.A. Isab, C.F. Shaw III and J. Locke, Inorg. Chem. 27 (1988), 3406.

[39] C.F. Shaw III, Comments Inorg. Chem. 8 (1989), 233.

[40] A.A. Isab, A.L. Hormann, D.T. Hill, D.E. Griswold, M.J. Dimartino and C.F. Shaw III, Inorg. Chem. 28 (1989), 1321.

[41] A.A. Isab, C.F. Shaw III, A. Munoz and J.D. Hoeschele, Inorg. Reaction Mech. 5 (2004), 109.

[42] A.A. Isab, C.F. Shaw III, J.D. Hoeschele and J. Locke, Inorg. Chem. 27 (1988), 3588.

[43] C.F. Shaw III, A.A. Isab, J.D. Hoeschele, M. Starich, J. Locke, P. Schulteis and J. Xiao, J. Am. Chem. Soc. 116 (1994), 2254.

[44] J. Xiao and C.F. Shaw III, Inorg. Chem. 31 (1992), 3706.

[45] J. Christodoulou, P.J. Sadler and A. Tucker, FEBS Letters 376 (1995), 1.

[46] D.C. Carter and J.X. Ho, Adv. Prot. Chem. 45 (1994), 153.

[47] O.M.N. Dhubhghalli, P.J. Sadler and A. Tucker, J. Am. Chem. Soc. 114 (1992), 1118.

[48] N.A. Malik, G. Otiko and P.J. Sadler, J. Inorg. Biochem. 12 (1980), 317.

[49] A.A. Isab, J. Chem. Soc., Dalton Trans. (1986), 1049.

[50] A.A. Isab, Inorg. Chim. Acta 135 (1987), 19.

[51] S. Ahmad and A.A. Isab, J. Coord. Chem. 55 (2002), 189.

[52] A.A. Isab, A.R. Al-Arfaj and M.N. Akhtar, J. Coord. Chem. 33 (1994), 287.

[53] A.A. Isab, Inorg. Chim. Acta 207 (1993), 73.

[54] A.A. Isab, S. Ahmad, A.R. Al-Arfaj and M.N. Akhtar, J. Coord. Chem. 56 (2003), 95.

[55] A.A. Isab, J. Inorg. Biochem. 46 (1992), 145. 
[56] S. Ahmad and A.A. Isab, J. Inorg. Biochem. 88 (2002), 44.

[57] A.A. Isab and S. Ahmad, J. Inorg. Biochem. 88 (2002), 53.

[58] J. Reglinski, S. Hoey and W.E. Smith, Inorg. Chim. Acta 152 (1988), 261.

[59] A.A. Mohamed, H.E. Abdou, J. Chen, A.E. Bruce and M.R.M. Bruce, Comm. Inorg. Chem. 23 (2002), 321.

[60] R. Narayanaswamy, M.A. Young, E. Parkhurst, M. Ouellette, M.E. Kerr, D.M. Ho, R.C. Elder, A.E. Bruce and M.R.M. Bruce, Inorg. Chem. 32 (1993), 2506.

[61] G.G. Graham and M.M. Dale, Biochem. Pharm. 39 (1990), 1697.

[62] G.G. Graham and A.J. Kettle, Biochem. Pharm. 56 (1998), 307.

[63] R.C. Elder, Z. Zhao, Y. Zhang, J.G. Dorsey, E.V. Hess and K. Tepperman, J. Rheumatol. 20 (1993), 268.

[64] A.J. Canunumalla, S. Schraa, A.A. Isab, C.F. Shaw III, E. Gleichman, L. Dunemann and M. Turfeld. J. Biol. Inorg. Chem. 3 (1998), 9.

[65] G.G. Graham, T.M. Haavisto, H.M. Jones and G.D. Champion, Biochem. Pharm. 33 (1984), 1257.

[66] G.G. Graham, T.M. Haavisto, P.M. McNaught, C.D. Browne and G.D. Champion, J. Rheum. 9 (1982), 527.

[67] D.W. James, N.W. Ludvigsen and L.G. Cleland, J. Rheum. 9 (1982), 532.

[68] A.A. Isab, M.N. Akhtar and A.R. Al-Arfaj, J. Chem. Soc. Dalton Trans. (1995), 1483.

[69] S. Ahmad, Coord. Chem. Rev. 248 (2004), 231.

[70] A.L. Hormann, C.F. Shaw III, D.W. Bennett and W.M. Reiff, Inorg. Chem. 25 (1986), 3953.

[71] A.L. Hormann and C.F. Shaw III, Inorg. Chem. 29 (1990), 4683.

[72] A.A. Isab, M.S. Hussain, M.N. Akhtar, M.I.M. Wazeer and A.R. Al-Arfaj, Polyhedron 18 (1999), 1401.

[73] S. Ahmad, A.A. Isab and H.P. Perzanowski, Can. J. Chem. 80 (2002), 1279.

[74] S. Ahmad, A.A. Isab, A.R. Al-Arfaj and A.P. Arnold, Polyhedron 21 (2002), 2099.

[75] R.D. Hancock, N.P. Finnkelstein and A. Avers, J. Inorg. Nucl. Chem. 34 (1972), 3747.

[76] K. Tepperman, Y. Zhang, P.W. Roy, R. Floyd, Z. Zhao, J.G. Dorsey and R.C. Elder, Met. Based Drugs 1 (1994), 433.

[77] A. Sano, N. Takimoto and S. Takitani, J. Chromatogr. 582 (1992), 131.

[78] C.J. Vesey and J. Wilson, J. Pharm. Pharmacol. 30 (1978), 20.

[79] R.J. Puddephatt, The Chemistry of Gold, Elsevier, New York, 1978, 4, 45-47.

[80] A.J. Canumalla, N. Al-Zamil, M. Philips, A.A. Isab and C.F. Shaw III, J. Inorg. Biochem. 85 (2001), 67.

[81] Y. Zhang, E.V. Hess, K.G. Pyrhuber, J.G. Dorsey, K. Tepperman and R.C. Elder, Inorg. Chim. Acta 229 (1995), 271.

[82] G. Lewis and C.F. Shaw III, Inorg. Chem. 25 (1986), 58.

[83] P.N. Dickson, A. Wehrli and G. Geier, Inorg. Chem. 27 (1988), 2921

[84] S.J. Berners-Price, M.E. Sant, R.I. Christopherson and P.W. Kuchel, Mag. Res. Medicine 18 (1991), 142.

[85] S.J. Berners-Price and P.J. Sadler, J. Inorg. Biochem. 31 (1987), 267.

[86] S.J. Berners-Price, C.K. Mirabelli, R.K. Johnson, M.R. Mattern, F.L. McCabe, L.F. Faucette, C.M. Sung, S.M. Mong, P.J. Sadler and S.T. Crooke, Cancer Res. 46 (1986), 5486.

[87] S.J. Berners-Price, G.R. Girard, D.T. Hill, B.M. Sutton, P.S. Jarrett, L.F. Faucette, R.K. Johnson, C.K. Mirabelli and P.J. Sadler, J. Med. Chem. 33 (1990), 1386.

[88] S.J. Berners-Price and P.J. Sadler, Structure and Bonding 70 (1988), 27.

[89] S.J. Berners-Price, P.S. Jarrett and P.J. Sadler, Inorg. Chem. 26 (1987), 3074.

[90] F. Caruso, M. Ross, J. Tanski, C. Pettinari and F. Marchetti, J. Med. Chem. 46 (2003), 1737. 


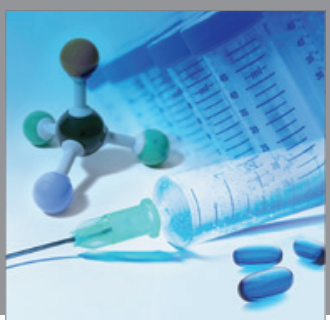

International Journal of

Medicinal Chemistry

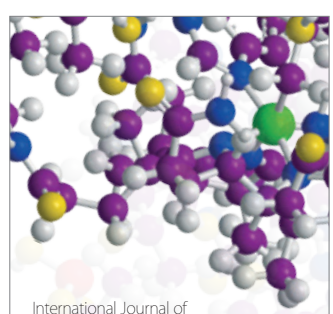

Carbohydrate Chemistry

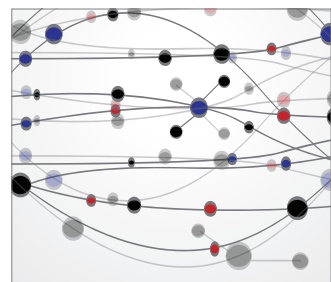

The Scientific World Journal
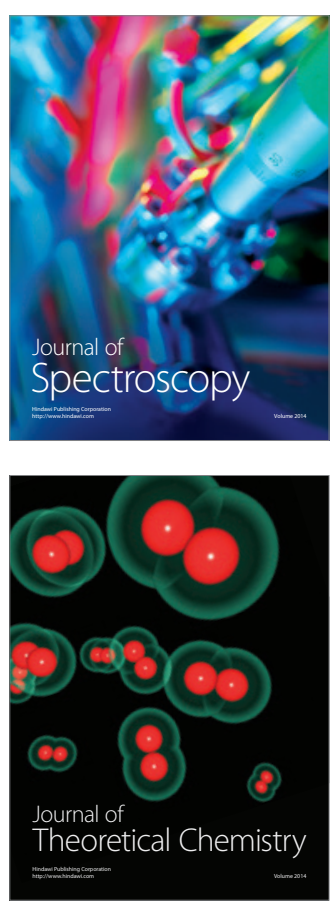
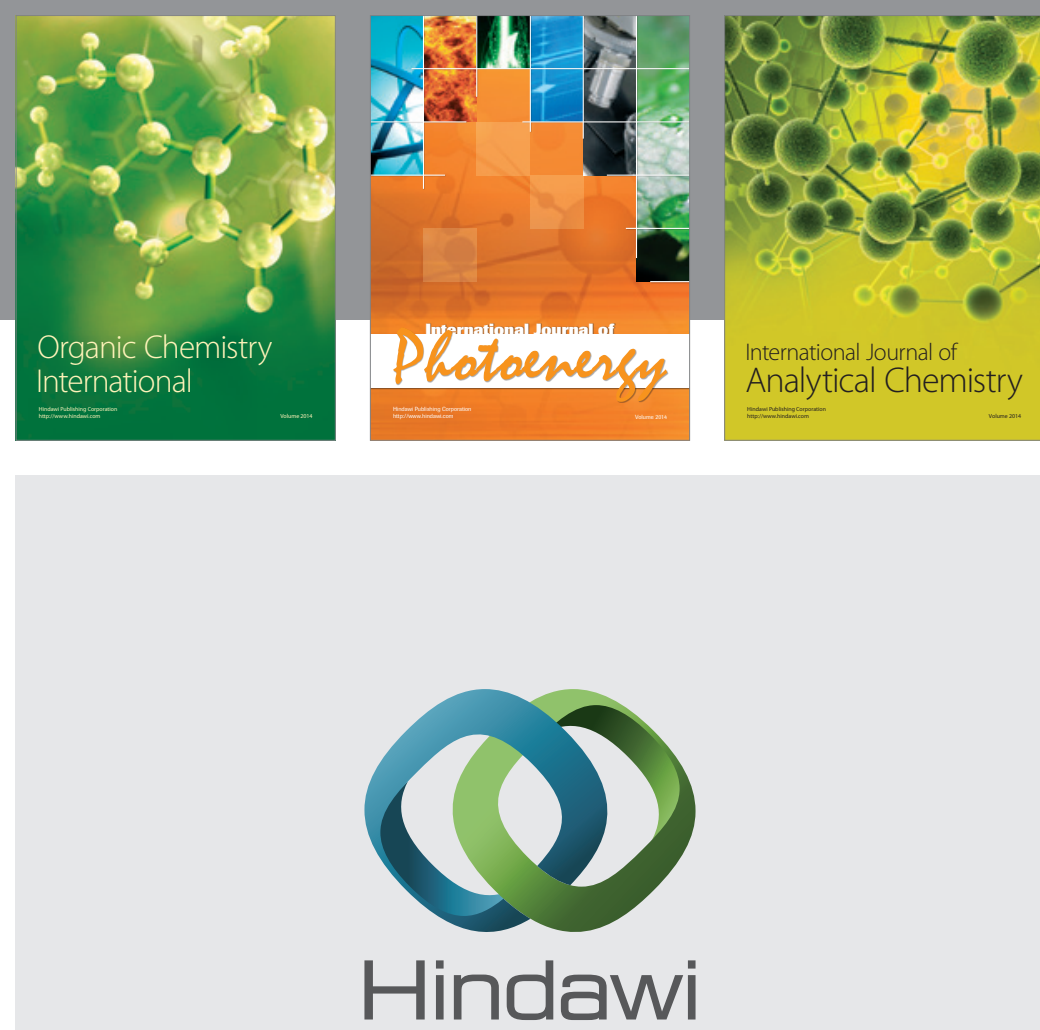

Submit your manuscripts at

http://www.hindawi.com
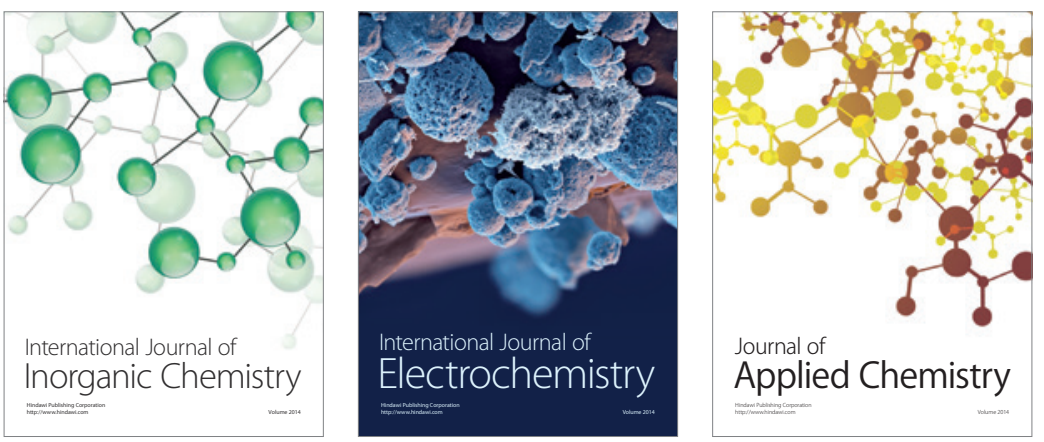

Journal of

Applied Chemistry
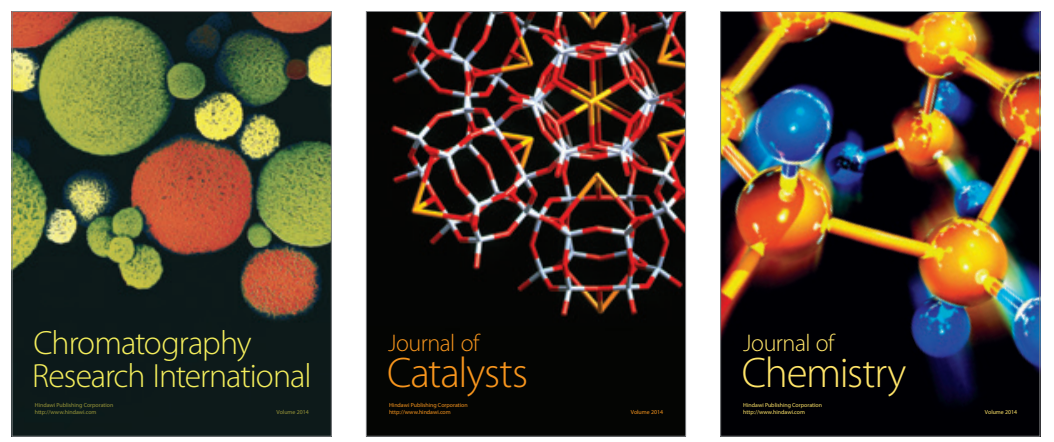
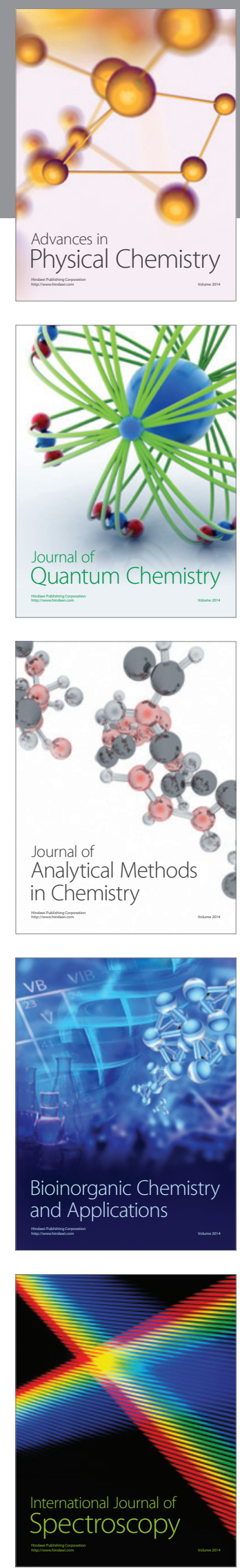